\title{
Strategi Pemasaran Oleh Pengusaha Perempuan di Kabupaten Jember
}

Muhammad Rijalus Sholihin

STIE Widya Gama Lumajang

rijalussantri@gmail.com

\begin{abstract}
Abstrak
Usaha mikro kecil menengah merupakan ujung tobak bagi kesejahteraan masyarakat, terlebih perkembangan ternolog informasi yang semakin kua juga harus dimanfaatkan oleh setiap pelaku usaha. Banyak cara yang bisa dilakukan dalam memalukan usaha mulai dari manual dengan bertatap muka maupun dengan media online seperti saat ini, hal ini yang benar-benar harus dikuasai oleh pelaku usaha. Banyaknya pedagang sayuran yang seakan terus erkembang sudah pasti mereka mempunyai cara tersendiri dalam memasarkan setiap produk yang dimiliki, namun terkadang kurangnya penguasaan teknologi informasi yang minim membuat mereka sering kalah saing dengan yang bermodal teknologi informasi seperti saat ini. Melalui penelitian ini diharapkan akan ditemukannya strategi pemasaran yang baik dan benar guna mengembangkan usaha yang dilakukan oleh para pengusaha perempuan pedagang sayuran khususnya di Kevamatan Umbulsari Kabupaten Jember.
\end{abstract}

\section{Kata kunci : Pengusaha Perempuan, Strategi Pemasaran, Pasar Tradisional}

\begin{abstract}
Small and medium-sized micro-enterprises are the tip of the community for the welfare of the community, especially the development of information technology that is increasingly well used by every business actor. There are many ways that can be done in embarrassing businesses ranging from face-to-face manuals and online media as it is today, which really must be mastered by business people. The number of vegetable traders who seem to continue to grow is certain they have their own way of marketing every product they have, but sometimes the lack of mastery of information technology that is minimal makes them often lose competitiveness with those with information technology as it is today. Through this research, it is hoped that a good and correct marketing strategy will be found to develop the business carried out by women entrepreneurs of vegetable traders, especially in the Umbulsari District of Jember.
\end{abstract}

\section{Keywords: Women Entrepreneurs, Marketing Strategies, Traditional Markets}

\section{PENDAHULUAN}

Usaha kecil menengah merupakan ujung tombak bagi kemakmuran masyarakat Indonesia, oleh sebab itu strategi pemasaran dalam siste yang dilakukan harus dilakukan oleh para pelaku usaha tersebut. Meskipun pada dsarnya tidak sedikit para pelaku usaha yang merem akan teknologi informasi yang dikendarai berbagai faktor seperti pendidikan yang minim, dan kurangnya pengalaman termasuk minimnya modal usaha. Jika kita pergi ke berbagai tempat belanja tidak jarang kitta temui kaum wanita menwarkan berbagai jasa maupun barang dagang yang mereka pasarkan, termasuk pedagang sayuran pada sebuah pasar tradisional, meskipun pada dasarnya bekerja sebagai tulang punggung adalah keajiban seorang suami, namun justru dpasar tradisional tersebut paling banyak dijumpai adalah kau wanita.Pendidikan yang rendah dan masih sedikitnya penguasaan teknologi informasi sering membuat para pelaku usaha harus memutar otak dalam memasarkan dagangan mereka, tidak terkecuali para pedagang sayuran di kecamatan umbulsari kabupaten Jember ini.

Dengan semakin banyaknya seorang istri yang bekerja membantu suami dalam memenuhi kebutuhan keluarga maka hal ini juga mampu meningkatkan taraf hidup mereka menjadi lebih baik dari sebelumnya. Dengan demikian sebuah peluang usaha terkadang muncul dari pemikiran dan tindakan yang dilakukan oleh para perempuan (Rijalus, 2018). Selain membantu seorang suami dalam memenuhi kebutuhan hidup, terkadang seorang istri mempunyai alasan lain kenapa mereka melakukan sebuah bisnis atu bekerja pada suatu perusahaan, sebab suami yang mapan terkadang masing sering kita temui istrinya juga bekerja kantoran namun dengan dengan berbagai alasan, oleh seban itu strategi pemasaran perlu dikuasi demi kelangusngan usaha perempuan. Dalam hal ini masih sering kita jumpai seorang pengusaha perempuan yang dagangnnyatidak lekas habis, bahkan membusuk bagi mereka para pelaku usaha pedagang sayuran, yang mana hal ini akan membuat mereka seakan merasa terus merugi, dengan demikian perlu adanya strategi tersendiri dalam memasarkan barang dagangan yang mereka miliki.

\section{KAJIAN TEORI}


Usaha Mikro, Kecil, dan Menengah (UMKM) memiliki definisi yang berbeda pada setiap literatur menurut beberapa instansi atau lembaga bahkan undang-undang. Sesuai dengan Undang-Undang nomor 20 tahun 2008 tentang Usaha Mikro, Kecil, dan Menengah, UMKM didefinisikan sebagai berikut:

1. Usaha mikro adalah usaha produktif milik orang perorangan dan/atau badan usaha perorangan yang memenuhi kriteria Usaha Mikro sebagaimana diatur dalam Undang-Undang ini.

2. Usaha Kecil adalah usaha ekonomi produktif yang berdiri sendiri, yang dilakukan oleh orang perorangan atau badan usaha yang bukan merupakan anak perusahaan atau bukan cabang perusahaan yang dimiliki, dikuasai, atau menjadi bagian baik langsung maupun tidak langsung dari Usaha Menengah atau Usaha Besar yang memenuhi kriteria Usaha Kecil sebagaimana dimaksud dalam Undang-Undang ini.

3. Usaha Menengah adalah usaha ekonomi produktif yang berdiri sendiri, yang dilakukan oleh orang perorangan atau badan usaha yang bukan merupakan anak perusahaan atau cabang perusahaan yang dimiliki, dikuasai, ataupun menjadi bagian baik langsung maupun tidak langsung dengan Usaha Kecil atau Usaha Besar dengan jumlah kekayaan bersih atau hasil penjualan tahunan sebagaimana diatur dalam Undang-Undang ini.

Berdasarkan kekayaan dan hasil penjualan, menurut Undang-Undang Nomor 20 tahun 2008 pasal 6, kriteria usaha mikro yaitu:

1. Memiliki kekayaan bersih paling banyak $\mathrm{Rp} 50.000 .000,00$ (lima puluh juta rupiah) tidak termasuk tanah dan bangunan tempat usaha; atau

2. Memiliki hasil penjualan tahunan paling banyak Rp 300.000.000,00 (tiga ratus juta rupiah).

Kriteria usaha kecil adalah sebagai berikut:

1. Memiliki kekayaan bersih lebih dari Rp 50.000.000,00 (lima puluh juta rupiah) sampai dengan paling banyak Rp 500.000.000,00 (lima ratus juta rupiah) tidak termasuk tanah dan bangunan tempat usaha; atau

2. Memiliki hasil penjualan tahunan lebih dari Rp $300.000 .000,00$ (tiga ratus juta rupiah) sampai dengan paling banyak Rp 2.500.000.000,00 (dua milyar lima ratus juta rupiah).

Sedangkan kriteria usaha menengah adalah sebagai berikut:

1. Memiliki kekayaan bersih lebih dari Rp 500.000.000,00 (lima ratus juta rupiah) sampai dengan paling banyak $\mathrm{Rp} 10.000 .000 .000,00$ (sepuluh milyar rupiah) tidak termasuk tanah dan bangunan tempat usaha; atau

2. Memiliki hasil penjualan tahunan lebih dari $\mathrm{Rp} 2.500 .000 .000,00$ (dua milyar lima ratus juta rupiah) sampai dengan paling banyak Rp 50.000.000.000,00 (lima puluh milyar rupiah).

Dalam hal ini, UMKM ditutut untuk mampu bersaing dan menciptakan produk yang dapat diterima tidak hanya oleh konsumen dalam negeri (Indonesia) tetapi juga konsumen di Asia Tenggara. Usaha mikro, kecil dan menengah (UMKM) selalu hadir karena memang diperlukan. UMKM ini selalu pula dapat membuktikan ketahanannya, terutama ketika bangsa kita dilanda badai krisis ekonomi (sejak Juli 1997). UMKM ini tampak merupakan salah satu sektor usaha penyangga utama yang dapat menyerap banyak tenaga kerja

\section{Peran Wirausaha Perempuan}

Keterlibatan perempuan dalam wirausaha, menjadi kajian beberapa peneliti, di antaranya Ardhanari (2007), yang meneliti profil dan hambatan wirausaha perempuan di Indonesia untuk berkembang. Temuannya sangat menarik karena disebutkan hambatan wirausaha perempuan adalah karakteristik personal yang diakibatkan oleh beban kerja akibat peran ganda seorang perempuan dan karakteristik struktural, yaitu hambatan terhadap akses permodalan (syarat dan agunan) dan akses pemasaran di mana perempuan memiliki akses informasi pemasaran yang rendah. Disimpulkan bahwa hambatan perkembangan wirausaha perempuan adalah akibat gender stereotype (stereotip gender) antara perempuan dan laki-laki dalam lingkungan patriarkhi. Wilson et al., 2007 penekanan penelitian pada faktor personal (personality characteristic), yaitu self-efficacy. Hasil penelitiannya memberikan data bahwa kaum perempuan memiliki self-efficacy dan self-confidence yang lebih rendah dari kaum laki-laki di bidang matematika, keuangan, pembuatan keputusan, dan problem solving. Padahal hal ini adalah faktor utama yang berhubungan dengan keterampilan dan keahlian laki-laki dan bahkan menjadi determinan dalam mendorong kesuksesan sebagai seorang wirausaha. Selaras dengan Kickkul et al., (2004) yang menyatakan bahwa self-efficacy kaum lakilaki lebih tinggi daripada perempuan. Padahal, self-efficacy ini menjadi faktor penting bagi wirausaha dalam mengembangkan dan menguasai skill yang dibutuhkan dan pada akhirnya akan berdampak terhadap kesuksesan karir.

\section{Strategi Pemasaran}

Setiap perusahaan mempunyai Strategi untuk mendukung aktivitas perusahaan dimana strategi harus sesuai dengan keadaan dan kondisi masyarakat. Strategi adalah suatu program yang mendukung untuk mencapai suatu tujuan perusahaan.

Amstrong (2003:39-42), mendefinisikan bahwa setidaknya terdapat tiga pengertian. Pertama, Strategi merupaka deklarasi maksud yang mendefinisikan cara untuk mencapai tujuan, dan memperhatikan 
sungguh-sungguh alokasi sumber daya perusahaan yang penting untuk jangka panjang dan mencocokkan sumber daya dan kapabilitas dengan lingkungan eksternal. Kedua, strategi merupakan perspektif dimana isu kritis atau factor keberhasilan dapat dibicarakan, serta keputusan strategis bertujuan untuk membuat dampak yang besar serta jangka panjang kepada prilaku dan keberhasilan organisasi. Ketiga, strategi pada dasarnya adalah mengenai penetapan tujuan (tujuan strategis) dan mengalokasikan atau menyesuaikan sumber daya dengan peluang (strategis berbasis sumber daya) sehingga dapat mencapai kesesuaian strategis dan basis sumber dayanya.

Berdasarkan keseluruhan definisi di atas, maka strategi dapat didefinisikan sebagai berikut : Sekumpulan pilihan kritis untuk perencanaan dan penerapan serangkaian rencana tindakan dan alokasi sumber daya yang penting dalam mencapai tujuan dasar dan sasaran, dengan memperhatikan keunggulan kompetitif,komparatif, dan sinergis yang ideal berkelanjutan, sebagai arah, cakupan, dan perpektif jangka panjang keseluruhan yang ideal dari individu atau organisasi.

Selanjutnya Kotler (2000:109), mendefinisikan bahwa pemasaran strategis adalah konsep yang menjelaskan tentang keputusan, analisis dan permasalahan pemasaran, penekanan terhadap pandangan organisasional daripada fungsional. Peran pemasaran berubah seiring dengan kesadaran akan pentingnya pelanggan bagi suatu perusahaan.

Dari definisi mengenai pemasaran di atas dapat disimpulkan bahwa proses pemasaran bertujuan untuk memuaskan konsumennya. Kunci utama untuk mencapai sasaran organisasi adalah dengan mengenali kebutuhan (needs) dan keinginan (wants) dari pasar sasarannya dan memberikan kepuasan kepada konsumen dengan cara yang lebih efektif dan efisien dibandingkan pesaingnya

\section{Jenis-Jenis Strategi Pemasaran}

Untuk mengetahui jenis strategi pemasaran mana yang tepat dan sesuai dengan perusahaan perlu terlebih dahulu mengetahui jenis dan bentu kebutuhan konsumen, sebelum perusahaan memasarkan produk yang diproduksikan.

Untuk lebih jelasnya Tedjasatesan (2001:42) Mengatakan Strategi pemasaran dapat dibagi kedalam empat jenis dasar, yaitu :

1. Merangsang kebutuhan primer dengan menambah jumlah pemakai.

2. Merangsang kebutuhan primer dengan memperbesar tingkat pembeli.

3. Merangsang kebutuhan selektif dengan mempertahankan pelayanan yang ada

4. Merangsang kebutuhan selektif dengan menjaring pelanggan yang ada

Untuk lebih jelas Guiltinan (1994:159) mengatakan bahwa strategi pemasaran terdiri dari :

1. Strategi Kebutuhan Primer

Strategi kebutuhan primer dirancang terutama untuk menaikan tingkat permintaan akan bentuk atau kelas produk dari bukan pemakaian sekarang ( yang tidak ada atau hanya mempunyai sedikit pesaing saja ) serta produk-produk dengan bagian pasar yang besar kemungkinan besar akan mendapat manfaat dari strategi yang dirangcang untuk meningkatkan jumlah pemakai bentuk produk.

2. Strategi Kebutuhan Selektif

Strategi kebutuhan selektif dirancang untuk memperbaiki posisi pesaing suatu produk,jas atau bisnis. Fokus dasar dari strategi-strategi ini adalah pada bagian pasar,karena perolehan penjualan diharapkan akan dating dengan mengembangkan bentuk produk satu kelas pesaing. Strategi kebutuhan selektif dapat dicapai dengan mempertahankan pelanggan lama atau dengan menyaring pelanggan baru.

Tabel 1. Penelitian Terdahulu

\begin{tabular}{|c|c|c|c|c|c|}
\hline $\begin{array}{c}\text { Tema } \\
\text { Penelitian }\end{array}$ & $\begin{array}{l}\text { Nama } \\
\text { Peneliti }\end{array}$ & $\begin{array}{c}\text { Tahun } \\
\text { Penelitian }\end{array}$ & $\begin{array}{c}\text { Judul } \\
\text { Penelitian }\end{array}$ & $\begin{array}{c}\text { Metode } \\
\text { Penelitian }\end{array}$ & Hasil Penelitian \\
\hline $\begin{array}{l}\text { Strategi } \\
\text { Pemasaran }\end{array}$ & $\begin{array}{l}\text { Arlina } \\
\text { Nurbaity } \\
\text { Lubis }\end{array}$ & 2004 & $\begin{array}{l}\text { Strategi } \\
\text { Pemasaran } \\
\text { dalam } \\
\text { Persaingan } \\
\text { Bisnis }\end{array}$ & $\begin{array}{l}\text { menggunakan } \\
\text { metode } \\
\text { deskriptif, } \\
\text { dimana } \\
\text { metode ini } \\
\text { sesuai dengan } \\
\text { tujuan } \\
\text { penelitian. } \\
\text { Selain } \\
\text { menggunakan } \\
\text { penelitian } \\
\text { deskriptif } \\
\text { penelitian ini } \\
\text { juga } \\
\text { menggunakan } \\
\text { metode } \\
\text { kualitatif }\end{array}$ & $\begin{array}{l}\text { Strategi pemasaran yang } \\
\text { dibuat hendaknya } \\
\text { haruslah } \\
\text { mempertimbangkan } \\
\text { situasi dan keadaan } \\
\text { perusahaan baik keadaan } \\
\text { intern perusahaan itu } \\
\text { sendiri atau lingkungan } \\
\text { mikro perusahaan, } \\
\text { maupun keadaan ekstern } \\
\text { perusahaan atau yang } \\
\text { dikenal dengan } \\
\text { lingkungan makro } \\
\text { perusahaan. } \\
\text { Karena perusahaan yang } \\
\text { besar mungkin dapat } \\
\text { menerapkan stretegi }\end{array}$ \\
\hline
\end{tabular}




\begin{tabular}{|c|c|c|c|}
\hline $\begin{array}{l}\text { Analisis } \\
\text { Pemasaran } \\
\text { SWOT }\end{array}$ & $\begin{array}{ll}\text { Sriyanti } & 2010 \\
\text { Prawitas } & \\
\text { ari } & \end{array}$ & $\begin{array}{l}\text { Analisis } \\
\text { SWOT } \\
\text { sebagai } \\
\text { dasar } \\
\text { perumusan } \\
\text { strategi } \\
\text { Pemasaran } \\
\text { berdaya } \\
\text { saing (Studi } \\
\text { pada Dealer } \\
\text { Honda } \\
\text { Tunggul } \\
\text { Sakti di } \\
\text { Semarang) }\end{array}$ & $\begin{array}{l}\text { Penelitian ini } \\
\text { menggunakan } \\
\text { metode } \\
\text { deskriptif, } \\
\text { dimana } \\
\text { metode ini } \\
\text { sesuai dengan } \\
\text { tujuan } \\
\text { penelitian. } \\
\text { Selain } \\
\text { menggunakan } \\
\text { penelitian } \\
\text { deskriptif } \\
\text { penelitian ini } \\
\text { juga } \\
\text { menggunakan } \\
\text { metode } \\
\text { kualitatif }\end{array}$ \\
\hline
\end{tabular}

tertentu yang jelas tidak

bisa dilakukan oleh

perusahaan kecil.

Demikian pula

sebaliknya, bukanlah

menjadi sesuatu hal yang

jarang terjadi bahwa

perusahaan kecil dengan

strateginya sendiri

mampu menghasilkan

tingkat keuntungan yang

sama atau bahkan lebih

baik daripada perusahaan

besar.

Hasil penelitian

menunjukkan bahwa

strategi pemasaran yang

dilakukan

perusahaan adalah

Strategi Investasi, dimana

posisi perusahaan berada

di posisi

AMAN dan jenis

usahanya adalah usaha

IDEAL. Strategi Investasi

ini berarti

lingkungan perusahaan

mendukung untuk

melakukan investasi dan

kemudian

menuai hasil (harvesting).

Perusahaan dapat

menggunakan strategi

perusahaan

sebelumnya dengan

memperbaiki beberapa

kelamahan perusahaan

dan menghindari

atau bertahan melawan

ancaman perusahaan

dengan menciptakan

strategi yang lebih

berdaya saing

\begin{tabular}{|c|c|c|c|c|c|}
\hline $\begin{array}{l}\text { Penelitian } \\
\text { Sekarang }\end{array}$ & $\begin{array}{l}\text { Muham } \\
\text { mad } \\
\text { Rijalus } \\
\text { Sholihin }\end{array}$ & 2018 & $\begin{array}{l}\text { Strategi } \\
\text { Pemasaran } \\
\text { oleh } \\
\text { Pengusaha } \\
\text { Perempuan } \\
\text { di } \\
\text { Kabupaten } \\
\text { Jember }\end{array}$ & $\begin{array}{l}\text { Penelitan } \\
\text { Kualitatif }\end{array}$ & $\begin{array}{l}\text { Hasil penelitian } \\
\text { menunjukkan bahwa } \\
\text { UMKM di Kabupaten } \\
\text { Jember sudah berdaya, } \\
\text { dengan memaksimalkan } \\
\text { jaringan dan kecakapan } \\
\text { komunikasi dalam } \\
\text { memsarkan suatu produk } \\
\text { yang pasarkan, tetapi } \\
\text { dalam perjalanannya } \\
\text { perlu proses dalam } \\
\text { menyediakan variasi } \\
\text { produk, khususnya } \\
\text { produk-produk kreatif } \\
\text { guna lebih merik } \\
\text { perhatian para pelanggan }\end{array}$ \\
\hline
\end{tabular}

Sumber : Hasil Olahan Peneliti Tahun 2018 
Kerangka pemikiran pada penelitian ini berawal dari kasus yang sering dihadapi oleh para pelaku usaha yakni terbatasnya pengetahuan dan pengalaman dalam pendanaan sebuah usaha serta cara pengelolaan keuangn yang dirasa kurang mampu meningkatkan peningkatan penghasilan.

Adapun kerangka pemikiran penelitian tampak seperti gambar di bawah ini :

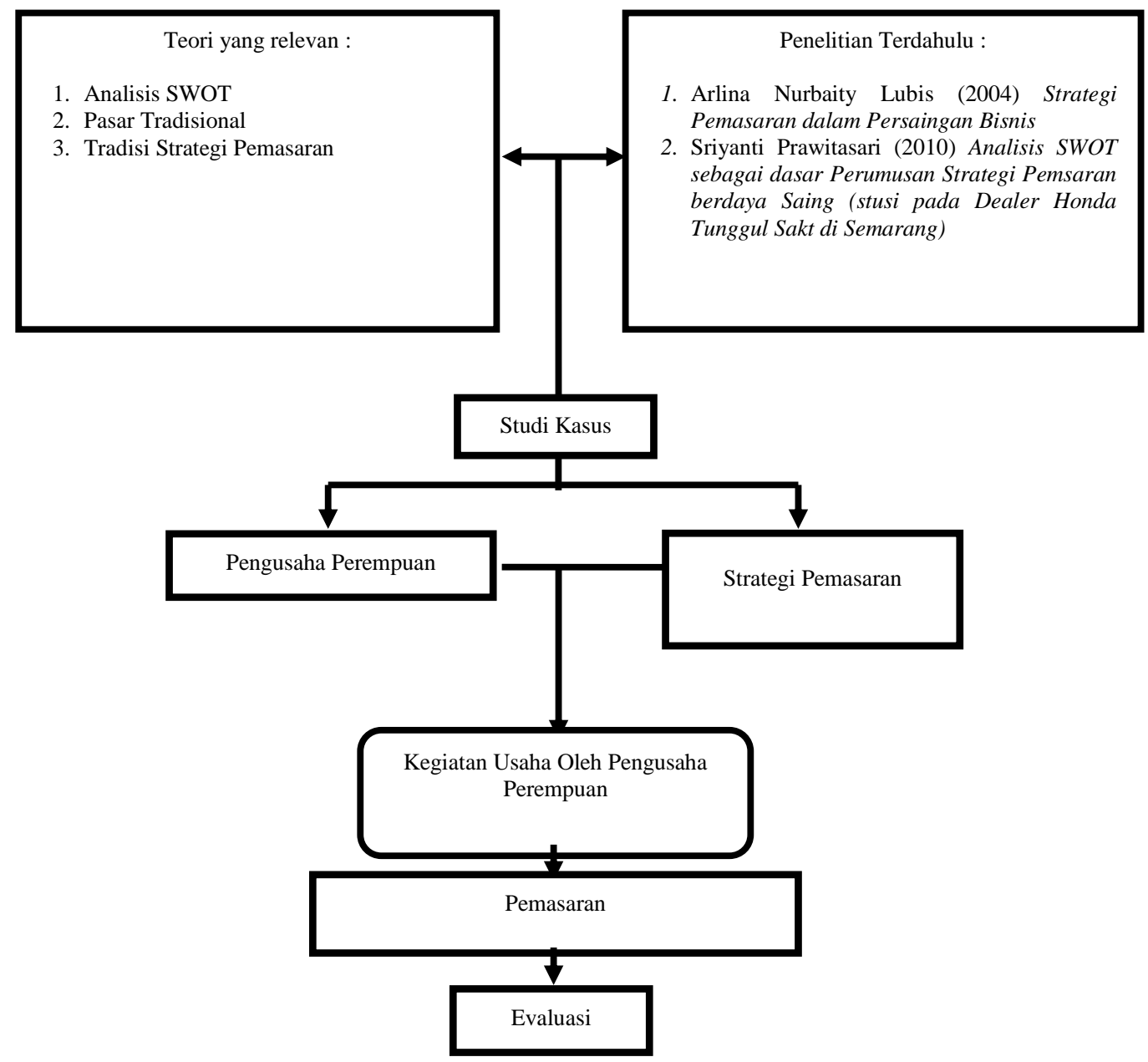

Gambar 1. Kerangka Pemikiran Penelitian

\section{METODOLOGI PENELITIAN \\ Jenis Penelitian}

Penelitian ini menggunakan metode kualitatif. Metode penelitian kualitatif sering disebut sebagai metode penelitian naturalistik karena penelitiannya dilakukan pada kondisi yang alamiah (natural setting) disebut juga sebagai metode etnographi, karena pada awalnya metode ini banyak digunakan untuk penelitian bidang antropologi budaya, disebut juga sebagai metode kualitatif, karena data yang terkumpul dan analisisnya lebih bersifat kualitatif. Penelitian kualtatif adalah penelitian yang tidak menggunakan modelmodel matematik, statistik atau komputer. Proses penelitian dimulai dengan menyusun asumsi dasar dan aturan berpikir yang akan digunakan dalam penelitian. Penelitian kualitatif merupakan penelitiian yang dalam kegiatannya peneliti tidak menggunakan angka dalam mengumpulkan data dan dalam memberikan penafsiran terhadap hasilnya.

Bogdan dan taylor mendefinisikan "metodologi kualitatif" sebagai prosedur penelitian yang menghasilkan data deskriptif berupa kata-kata tertulis atau lisan dari orang-orang dan perilaku yang dapat diamati. Sedangkan kirk dan miller mendefinisikan bahwa penelitian kualitatif adalah tradisi tertentu dalam ilmu pengtahuan sosial yang secara fundamental bergantung pada pengamatan pada manusia dalam kawasannya sendiri dan berhubungan dengan orang-orang tersebut dalam bahasannya dan dalam peristilahannya. Metodologi penelitian merupakan sesuatu yang berusaha membahas konsep teoristik berbagai metode, kelebihan dan kelemahan-kelemahannya yang dalam karya ilmiah dilanjutkan dengan pemilihan metode yanng akan digunakan. Dalam hal ini metode lebih bersifat teknis pelaksanaan lapangan sedangkan metodologi lebih pada uraian filosofis dan teoritisnya. Oleh karena itu penetapan sebuah metodologi penelitian mengandung implikasi inheren di dalam diri filsafat yang dianutnya. Sebab filsafat ilmu yang melandasi berbagai metodologi penelitian yang ada. Maka dari itu dengan mengetahui metodologi 
penelitian yang digunakan, filsafat ilmu dan kajian teoritisnya, kelemahan dan kelebihannya diharapkan akan mampu memberikan kesesuaian metodologi dengan fokus masalah penelitian.

Objek penelitian kualitatif adalah seluruh bidang/aspek kehidupan manusia, yakni manusia dan segala sesuatu yang dipengaruhi manusia. Objek itu diungkapkan kondisinya sebagaimana adanya atau dalam keadaan sewajarnya (natural setting), mungkin berkenaan dengan aspek/bidang kehidupannya yang disebut ekonomi kebudayaan, hukum, administrasi, agama dan sebagainya. Data kualitatif tentang objeknya dinyatakan dalam kalimat, yang pengolahannya dilakukan melalui proses berpikir (logika) yang bersifat kritik, analitik/sintetik dan tuntas.

\section{Unit Analisis}

\section{Lokasi Penelitian}

Lokasi penelitian berada di Kecamatan Umbulsari, Kabupaten Jember. Alasan utama yang menjadi dasar pemilihan penelitian di daerah tersebut, antara lain :

1. Terdapatnya pasar tradisional yang selalu ramai setiap harinya dengann berbagai banyak konsumen termasuk jenis barang dagangan seperti sayuran dan lain-lain.

2. Kecamatan Umbulsari merupakan kawan pedesaan yang memiliki pasar tradisional dan sudah mulai berbenah ke kawasan pasar tradisional yang berseri, yaitu penataan antara masing-masing jenis pedagang sudah mulai terpisah tidak tercampur antara pedagang makanan dan pakaian, sehhingga membuat konsumen lebih nyaman dalam berbelanja

3. Terdapatnya berbagai macam jenis pedagang terlebih pengusaha sayuran yang didominasi oleh perempuan membuat peneliti lebih mudah dalam mencari informan dan mendapatkan informasi sebagai bahan kajian penelitian.

\section{Informan Penelitian}

Informan penelitian adalah orang yang mampu memberikan informasi tentang situasi dan kondisi penelitian. Informan yang baik menurut Goezt dan Lacomte (1984) adalah individu yang memiliki pengetahuan khusus, status atau ketrampilan komunikasi yang berkemauan untuk membagi pengetahuan dan yang memiliki akses serta observasi yang meniadakan peneliti. Berdasarkan beberapa pertimbangan tersebut maka informan penelitian yang dipilih menjadi informan kunci sumber informasi, antara lain adalah : Ibu Ainur Rofi'ah, Selaku Pengusaha sayuran yang beralamat di Dusun Jatilawang Desa Tegalwangi Kecamatan Umbulsari, Kabupaten Jember, dan Ibu Siti Mufidah, selaku pedagang sayuran yang beralamat di Dusun Purwosari Desa Tanjungsari Kecamatan Umbulsari Kabupaten Jember.

\section{PEMBAHASAN}

\section{Gambaran Umum Objek Penelitian}

Profil Pengusaha Ibu Ainur Rofi'ah

Seorang ibu rumah tangga yang hanya berpendidikan tidak lebih dari Sekolah Dasar terkadang membuat membuat seseorang terlalu pesimis dalam melakukan sebuah usaha, namun hal tersebut tidak bagi Ibu rumah tangga dengan dua anak yang hanya berpendidikan Madrasah Ibtidaiyah, yaitu ibu Ainur Rofi'ah kelahiran Jember, 01 Juni 1982 yang beralamat di Dusun Jatilawang RT. 02 RW 08 Desa Tegalwangi Kecamatan Umbulsari Kabupaten Jember. Pada saat dimintai keterangan mengenai stratgei pemasaran yang dilakukan selama ini beliau dengan sangat tegas dan lugas mengatakan strategi yang dilakukan selama ini, mulai dari dia belum tahu dan belum ngenal pasar hingga sudah lihai dalam memasarkan barang dgangan dipasar tradisional.

"Saya melakukan usaha berdagang ini beajar dari nol alias tidak mengenal dan memiliki pengetahuan apapun mengenai pasar trandisional, terlebih bagaimana cara memasarkan produk barang dagangan yang baik dan benar agar mampu menarik minat pembeli dalam menwar dan membeli barang dagangan yang saya jual, sebab tekanan ekonomi juga yang mendorong saya untuk selalu berusaha belajar memasarkan barang dagangan dengan baik dan laku dipasaran"

"Pada dasarnya saya tidak memiliki strategi khusus dalam memasarkan barang dagangan yang saya jual, hanya saja saya selalu menganalisa pasar dan mencari harga terbaik dalam memasarkan barang dagangan, misalnya dengan cara mencari dan membeli barang dagangn dari petani langsung dengan harga yang rendah tanpa harus membeli kepada pengepul, namun terkadang saya juga mengambil barang dagangan dari pengepul sebagai upaya memenuhi stok barang dagangan yang jarang ada dipasar tradisional tempat saya berjualan, dengan demikian saya akan mampu bersaing dengan para pedagang lainnya".

"Dalam menjual barang dagangan saya juga selalu belajar mencari tahu harga terbaik para pesaing yang nantinya barang dagangan saya akam saya jual dibawah harga pasaran dari pedagang lainnya, walaupun sebenernya barang dagangan tersebut hanya berselisih 100 sampai 500 rupiah, namun hal ini akan berdampak pada minat pembeli para pelanggan terhadap barang dagangan yang saya jual"

"Strataegi lain yang saya gunakan adalah dengan membeli ibuhan terhadap pelanggan yang membeli dengan jumlah tertentu, sehingga mereka seakan merasa sangat dihargai dalam membeli barang dgangan dan merasa diperhatikan oleh penjuala" 
Memang menjadi seorang pengusaha bukanlah hal yang mudah, namun dengan penuh keyakinan semangat dan tetap mau belajar beliau telah membuktikan bahwa dia mampu. Adapu beberapa jenis sayuran yang sering beliau jual adalah sawi, bayam, kacang panjang, terong, brokoli, dan beberapa jenis sayran lainnya. Dalam diskusi kedua kami menanyakan bagaimana cara mengembangkan usaha hingga mampu eksis sampai saat ini.

"Dalam strategi pengembangan usaha sama halnya denga strategi pemasaran sebenernya, saya tidak ada cara tersediri, intinya saya selalu belajar dari pengalaman yang telah terjadi, itu saja, karena dengan hal tersebut kita mampu membenahi setiap kekurangan yang ada dalam proses pemasaran dan pengembangan usaha ini"

"Namun ada sedikit cara tersediri yang mungkin sebenernya juga sudah bukam rahasia umu mengenai strategi pemaaran yang saya lakukan selama ini, yaitu dengan menanam sendiri tanaman sayuran untuk dijual di pasar tradisional tanpa harus mengandalkan dari para petani yang menyetor hasil panennya ke saya, dengan demikian akan ada banyak untung yang saya dapatkan dibanding saya membeli dari petani"

"Karena waktu terkadang juga terbatas saya harus bisa membagi strategi, yang mana tidak selalu mengesampingkan kepentingan para petani saat mereka panen, agar misal saat saya tidak panen saya akan tetap berjualan sayuran dipasar dengan barang dagangan milik petani, dengan hal ini usaha yang saya geluti akan terus berkembang dan eksis meskipun musim berganti-ganti dan tidak menentu seperti saat ini"

"dalam beberapa tahun terakhir ini musim menag sedang menentu membuat banyak hasil sayuran yang tidak masimal, sehingga saya harus keluar daerah untuk membeli barang dagangan dari pengepul lain sebagai bahan barang dagangan saya, dan ternyata disitu saya menemukan banya barang dagangan yang tidak dijual pada pasar tradisional tempat saya berjualan setiap harinya, mungkin ini juga menjadi salah satu strategi yang bisa dilakukan oleh pedagang sayuran lain untuk jangan mengandalkan satu atau dua petani sebagai penghasil sayuran agar pada musim yang tidak menentu masih sanggup dan bisa berjualan seperti hari-hari biasanya"

Dari penjelasan diatas bahwa menjadi pengusaha tidak harus selalu dengan bertani dan bersumber dari diri kita sendiri, namun dengan keyakinan, usaha dan kerja keras dan pantang menyerah keberhasilan bisa tercapai, meski kegagalan sering terjadi namun ke optimisan membuat sesorang mampu untuk tetap bertahan dengan apa yang dia jalani. Ibu Ainur telah membuktikan bahwa dengan modal sedikit namun dengan kegigihan semua harapan dapat tercapai, kini beliau selain menanam sayuran sendiri juga membeli dari para pengepul sayuran bahkan dari petani langsung dengan harha yang seing naik turun namun tetap bisa memasarkannya.

Dari penjelasan diatas kita dapat menjabarkan bahwa berjualan itu sudah pasti ada persaingan, namun cara bersaing seperti apa yang setiap alami selalu berbeda, jika kita cermatti kembali apa yang dikatakan oleh ibu Ainur ada benanya juga mengenai menjual dibawah hara pasar namun masih mendapatkan untung meskipun tidak sebanyak jika menjualnya diharga pasar atau diatasnya, terlebih sekarang permainan harga sering dikuasi oleh para pelaku usaha besar yang menjadi patokan dalam memasarkan barang dagangan.

Kawasan dalam dalam berwirausaha juga menjadi salah satu pertibangan dalam menjalankan usaha, sebab segmen pasar seperti apa kita juga harus paham demi menjajakkan barang dagangan, terlebih kawasan jga menjadi faktor penentu mangsa pasar maupun penyedia barang dagang, meski tekadang penyedia barang dagang bisa didapatkan dari kawasan lain namun tetap mangsa pasar yanng telah kita tetntukan harus benar-benar mampu menyerap barang dagangan yang kita jual, jangan sampai sampai barang tersebut busuk mdan tidak laku akibat sengmen psar yang tidak tepat.

Kecamatan Umbulsari merupakan daerah pedesaan berkembang yang memiliki pasar tradisional dengan konsep semua barang dagang dapat dijual belikan disana, bukan hanya satu jenis usaha yang ada dan dipasarkan, sehingga mampu menampung semua para pelaku usaha, bertempat ditengahh kecamtan membuatnya banyak masyarakat yang tidak enggan untuk mencari kebutuhan dipasar tradionnal tersebut.

Ibu Ainur menjalankan usahanya sejak tahun 2002 hingga saat ini, yang mana tentunya sudah tahu bagaimana menangani setiap pelanggan yang dagang silih berganti menawar barang dagangannya, bukan hany sekali dua kali barang dagnganya tidak habis dipasar akibat persaingan yang ketat, tapi dengan segmen yang tepat membuat beliau mampu bertahan sampai sekarang.

Kedermawanan seseorang dalam berwirausaha juga ditunjukkan oleh beliau dalam kesehariannya, yang dibuktikan denga memberikan barang dagangn yang dikira tidak layak jual kepada tetangga yang membutuhkan, meski kelihatannya hal ini akan merugikan namun ternyata beliau mampu membuktikan bahwa kedermawanan justrus mampu mampu membuatnya bertahan dan berwirausaha dengan lancar sampai saat ini.

"Saya dulu tidak ada niatan menjadi seorang pengusaha sayuran, namun karena mertua keluar kota dan hanya harus menjual barang dagangnya agar tidak busuk dirumah maka saya memberanikan diri untuk kepasar dan memasarkannya, karena ini yang pertama saya juga sedikit benggung saat mengahadapi orang banyak terlebih proses memasarkan dan menawarkan barang dagangan" (Ibu Ainur Rofi'ah)

"Seperti yang saya katakatan tadi sebagai pengganti mertua dipasar jual sayuran kemudian mencoba belajar berjualan sendiri dengan membeli barang dagangan yang masih dalam pengawasan mertua waktu itu mas, jadi gak langsung tiba-tiba beli punya petani dengan harga sekian, saya selalu menanyakan tentang harga beli petani dan harga jual psar kepada mertua saat awal merintis usaha". (Ibu Ainur Rofi'ah) 


\section{Profil Pengusaha lbu Siti Mufidah}

Menjadi seorang pengusaha memang bukanlah hal yang mudah untuk dipelajari, terlebih jika sebagai tahap pemula dan belum ada pengalaman sama sekali, mungkin hal ini juga yang dialami oleh seorang pengusaha perempuan pedagang sayuran yaitu Ibu Siti Mufidah yang lahir di Jember, 19 Juni 1986 dan beralanat di Dusun Purwosari RT.01 RW.12 Desa Tanjungsari Kecamatan Umbulsari Kabupaten Jember, beliau hanya berpendidikan sampai Madrasah Tsanawiyah atau setingkat SMP, usaha sayurannya dirintis sejak usaha sang suami dirasa kurang mampu memenuhi kebutuhan sehari-hari, sehingga dia mencoba membantu dan memberi solusi dalam masalah ekonomi keluarga. Sang suami yang berpendidikan sampai Sekolah Dasar juga minim akan keahlian sehingga membuat neliau benar-benar membantu ekonomi keluarga, usaha sayuran ini baru dumulai tahun 2017 kemari sekitar awal bulan Maret setelah sang suami benar-benar kehabisan modal dalam menjalankan usaha sebelumnya yaitu berjualan makanan ringan secara keliling dari satu tempat ketempat lain.

Usaha dagang ini dia awali dengan modal seratus ribu yaitu dengan berjualan kecambah yang ia geluti sampai saat ini, itupun uang hasil pinjaman dari saudara yang juga berprofesi sebagai pedagang sayuran dan rela mencarikan tempat dipasar sebagai tempat berdagang.

Dalam pertemuan dengan beliau, banyak hal yang dapat saya simpulkan, termasuk menganai strategi usaha, hingga strategi penngembangan usaha hingga mampu bertahan sampai sat ini dan bisa dibilang semakin berkembang dari waktu kewaktu, bahan saat ini sayuran yang dijual sudah bermacam-macam yang beliau dapatkan dari membeli hasil panen para petani. Berikut tutur beliau saat ditemui dikediamannya.

"Pada dasarnya saya tidak memiliki banyak strategi Mas, hanya saja saya selalu memilih bahan berkualitas dan menjual dengan untung yang bisa dibilang tidak banyak asal cepat habis, sebab kan barang yang saya pasarkan ini mudakmsekalil busuk, jadi sayang kalau sampai berhari-hari tidak habis, oleh sebab itu saya tidak mengambil keuntungan yang besar, dengan prinsip barang cepat habis dan tidak tersisa, sehingga uangnya dapat diputar kembali sebagai modal usaha dan keuntungannya dipakai untuk kebutuhan sehari-hari".

"berhubung barang uatam yang saya pasarkan adalah kecambah saya selalu memilih bahan dasar kacang hijau yang berkualitas bagus tanpa menggunakan bahan kimia atau lainnya, sebab saya membunyai prinsip meskipun sedikit asal berkah mas, oleh sebab itu saya mengolahnya dengan sangat berhati-hati dan dengan proses tradisional banget, kita rutin mentiram setiap satu setengah jam sekali agar benih yang tumbuh sebagai kecambah dapat berkembang dengan baik, dan kita juga tidak menyiramnya dengan air yang bersumber dengan pipa, melainkan kita ambil dari ember dan saya siramkan secara merata keseluruh bagian yang akan tumbuh tersebut, sehingga barang yang dhasilkan akan sesuai, selain itu menguras sumur agar tetap jernih airnya juga kita lakukan agar menjaga kebersihan air yang digunakan dalam memproses kecambah tersebut".

"Dalam segi pemasaran saya lebih memilih menawarkan dengan harga dibawah pasar meskipun untung nggak banyak namun barang dapat habis terjual pada saat itu juga, tanpa ada sisa yang harus dibawa pulang kerumah".

"Memberikan imbuhan sesekali kepada pelanggan setia juga saya lakukan mas, biar mereka bebtah dan tetap mau beli disaya, ya sekarangn kalau beli dengan harga mahal dan nggak pernah dapat keringaanan siapa juga yang mau beli, pasti cari yang lain kan, makanya saya tidak mengutamakan egois dalam kepada pelanggan yang bener-bener setia mebeli barag dagangan saya, terlebih pada saat hari raya lebaran Idhul fitri sejenis bingkisan sederhana sudah pasti saya berikan, ya meskipun nilainya bisa dibiang nggak seberapa namun itun dapat menarik daya beli pelanggan setia secara tersediri, bukan malah sebaliknya".

"Dalam berjalannya waktu saya mencoba mengembangkan usaha dengan membeli barang dagangn dari para petani untuk dijual bersamaan dengan kecambah hasil olahan sendiri, dengan demikian pemasukan bukan hanya dari satu sumber saja".

Kegagalan memang selalu menghampiri dalam setiap usaha apapun, termasuk dalam berwirausaha seperti beliau, namun hak tersbeut bisa teratasi dengan belajar dari pengalaman yang telah terjadi, bukan berarti disaat seseorang jatuh langsung putus asa dan tidak mau berusaha kembali, hal tersebut sangat disayangkan sekali. Mencari pelanggan terkadang suka sering dianggap momok bagi pedagang atau wirausaha baru, namun produk yang lebih unggul bukan lagi hambatan justru mendatangkan pelangggan dengan sendirinya.

"Namun dalam waktu tententu saya juga mencoba mengalisa pasar mas, dengan mengurangi barang dagangan, hal ini bertujuan untuk meminimalisir sisa barang yang tidak terjual dan akan membusuk, biasanya hal ini biasanya terjadi akibat musim paceklik yang mana menanam sayur sulit dan perekonomian sedang tidak stabil, sehingga daya belli masyarakat menurun dan tidak menutup kemungkinan kita juga harus mensiasati hal ini sebagai dasar mengantisipasi keugian karena barang dagangan yang tidak habis terjual"

"Tapi yang pasti saya selalu mencoba barang dagangan yang yang saya jual selalu konsisten maksudnya barang dagangan yang saya jual selalu ada meskipun jumlahnya terkadang berkurang dari biasanya, hal ini sebagai upaya menanamkan rasa pengathuan kepada oembeli bahwa barang dagangan 
yang saya jual selalu ada kapanpun saat dibutuhkan meskipun jumlahnyantidak sebanyak pada musim rame dan panen"

Strategi dengan mengurangi persediaan barang dagang dagang juga merupakan setrategi yang cukup bagus, sebab disitu seseorang tidak menanggung resiko yang terlelu besar jika dibanding harus berdagang seperti biasa dengan bermodalkan hutang.

\section{Analisis Wacana}

Berdasarkan transkrip wawancara dengan nara sumber seperti yang telah diuraikan sebelumnya, para peneliti terfokus atas data-data yang diperoleh dari transkrip wawancara (data primer) dan data-data lain seperti catatan-catatan kecil dan gambar-gambar rancangan (sebagai data sekunder). Pertanyaanpertanyaan penelitian di awal digunakan sebagai pedoman analisis wacana hasil penelitian kali ini. Tematema yang ditemukan, diuraikan sebagai berikut:

\section{Kewirausahaan}

Pengusaha perempuan memang tidak sedikit kita jumpai dalam kehidupan sehari-hari disekeliling kita, namun demikian tidak jarang juga yang diantara mereka memiliki alasan yanng berbeda-beda, hal ini yang menjadi daya tarik tersendiri sekaligus sebagai motivasi pelaku usaha perempuan dalam menjalankan usahanya, sebab bukan karena paksaan atau sejenisnya melainkan sebuah hasil dari pemikiran yang matang dan berani menaggung resiko yang akan dihadapi, seperti yang dikutip dalam wawancara berikut:

"Saya dulu tidak ada niatan menjadi seorang pengusaha sayuran, namun karena mertua keluar kota dan hanya harus menjual barang dagangnya agar tidak busuk dirumah maka saya memberanikan diri untuk kepasar dan memasarkannya, karena ini yang pertama saya juga sedikit benggung saat mengahadapi orang banyak terlebih proses memasarkan dan menawarkan barang dagangan" (Ibu Ainur Rofi'ah)

"Seperti yang saya katakatan tadi sebagai pengganti mertua dipasar jual sayuran kemudian mencoba belajar berjualan sendiri dengan membeli barang dagangan yang masih dalam pengawasan mertua waktu itu mas, jadi gak langsung tiba-tiba beli punya petani dengan harga sekian, saya selalu menanyakan tentang harga beli petani dan harga jual psar kepada mertua saat awal merintis usaha". (Ibu Ainur Rofi'ah).

\section{Strategi Pemasaran dan Pengembangan Usaha}

Dalam dunia ppemasaran srategi pemasaran sangat dibutuhkan guna menarik pelanggan dan bersedia membeli barang yang kita tawarkan, banyak media informasi membuat persaingan dalam pemasaran harus juga ikut andil didalamnya meskipun pada dasarnya tidak semua orang mampu menjalankannya karena beberapa faktor salah satunya dalah kurangnya pemahaman atas pemanfaatan teknologi informasi itu sendiri, terlebih dengan para pelaku usaha tradisional seperti pedagang sayuran dan sejenisnya.

Setiap pelaku usaha tentunya mempunyai strategi tersendiri antara satu dengan yang lain, hal ini terbukti dengan beberapa strategi yang ada dalam permainan pasar yanng sering kita jumpai, mulai dari pembeian diskon, bonus, bahkan penawaran harga dengan dibawah rata-rata pasar. Dalam hal demikian tentunya setiap pelaku usaha sudah memiliki perhitungan yang matang dalam menjalankan strategi tersebut.

Dalam wawancara narasumber menuturkan beberapa hal mengenai strategi pemasaran yang dia sering lakukan dalam merain penaggan agar tertarik dan mau membeli barang dagangannya, berikut tuturnya:

"Strataegi lain yang saya gunakan adalah dengan membeli ibuhan terhadap pelanggan yang membeli dengan jumlah tertentu, sehingga mereka seakan merasa sangat dihargai dalam membeli barang dgangan dan merasa diperhatikan oleh penjuala" (Ibu Ainur Rofi'ah)

"Pada dasarnya saya tidak memiliki banyak strategi Mas, hanya saja saya selalu memilih bahan berkualitas dan menjual dengan untung yang bisa dibilang tidak banyak asal cepat habis, sebab kan barang yang saya pasarkan ini mudakmsekalil busuk, jadi sayang kalau sampai berhari-hari tidak habis, oleh sebab itu saya tidak mengambil keuntungan yang besar, dengan prinsip barang cepat habis dan tidak tersisa, sehingga uangnya dapat diputar kembali sebagai modal usaha dan keuntungannya dipakai untuk kebutuhan sehari-hari".

"berhubung barang uatam yang saya pasarkan adalah kecambah saya selalu memilih bahan dasar kacang hijau yang berkualitas bagus tanpa menggunakan bahan kimia atau lainnya, sebab saya membunyai prinsip meskipun sedikit asal berkah mas, oleh sebab itu saya mengolahnya dengan sangat berhati-hati dan dengan proses tradisional banget, kita rutin mentiram setiap satu setengah jam sekali agar benih yang tumbuh sebagai kecambah dapat berkembang dengan baik, dan kita juga tidak menyiramnya dengan air yang bersumber dengan pipa, melainkan kita ambil dari ember dan saya siramkan secara merata keseluruh bagian yang akan tumbuh tersebut, sehingga barang yang dhasilkan akan sesuai, selain itu menguras sumur agar tetap jernih airnya juga kita lakukan agar menjaga kebersihan air yang digunakan dalam memproses kecambah tersebut".

"Dalam segi pemasaran saya lebih memilih menawarkan dengan harga dibawah pasar meskipun untung nggak banyak namun barang dapat habis terjual pada saat itu juga, tanpa ada sisa yang harus dibawa pulang kerumah". 
"Memberikan imbuhan sesekali kepada pelanggan setia juga saya lakukan mas, biar mereka bebtah dan tetap mau beli disaya, ya sekarangn kalau beli dengan harga mahal dan nggak pernah dapat keringaanan siapa juga yang mau beli, pasti cari yang lain kan, makanya saya tidak mengutamakan egois dalam kepada pelanggan yang bener-bener setia mebeli barag dagangan saya, terlebih pada saat hari raya lebaran Idhul fitri sejenis bingkisan sederhana sudah pasti saya berikan, ya meskipun nilainya bisa dibiang nggak seberapa namun itun dapat menarik daya beli pelanggan setia secara tersediri, bukan malah sebaliknya".

"Dalam berjalannya waktu saya mencoba mengembangkan usaha dengan membeli barang dagangn dari para petani untuk dijual bersamaan dengan kecambah hasil olahan sendiri, dengan demikian pemasukan bukan hanya dari satu sumber saja".

"Namun dalam waktu tententu saya juga mencoba mengalisa pasar mas, dengan mengurangi barang dagangan, hal ini bertujuan untuk meminimalisir sisa barang yang tidak terjual dan akan membusuk, biasanya hal ini biasanya terjadi akibat musim paceklik yang mana menanam sayur sulit dan perekonomian sedang tidak stabil, sehingga daya belli masyarakat menurun dan tidak menutup kemungkinan kita juga harus mensiasati hal ini sebagai dasar mengantisipasi keugian karena barang dagangan yang tidak habis terjual"

"Tapi yang pasti saya selalu mencoba barang dagangan yang yang saya jual selalu konsisten maksudnya barang dagangan yang saya jual selalu ada meskipun jumlahnya terkadang berkurang dari biasanya, hal ini sebagai upaya menanamkan rasa pengathuan kepada oembeli bahwa barang dagangan yang saya jual selalu ada kapanpun saat dibutuhkan meskipun jumlahnyantidak sebanyak pada musim rame dan panen"

Dari penjelasan dua narasumber diatas menjelaskan bahwa mereka mempunyai strategi pemasaran yanng berbeda, yang mana ibu Ainur menggunakan sistem untung sedikit namun barang cepat habis dan nggak menyisakan barang dagang, dan ibu Mufidah lebih memilih memberi diskon atau keringanan pada setiap pelanggan yang setia membeli barang dagangnnya sehingga akan semakin banyak pelanggan yang tertarik untuk membeli barang dagangannya.

Setiap para pelaku usaha memang memiliki strateginya masing-masing dalam menarik pelanggan, selama itu tidak saling menjatuhkan pihak lain maka hal tersebut pantas dilakukan, namun lebih maksimalnya sebuat pemasaran jika mengikuti perkembangan ternologi informasi sehingga bukan hanya mampu bersaing dipasar tradisional namun pasar nasional bahkan internasional.

\section{KESIMPULAN DAN SARAN \\ Kesimpulan}

Berdasarkan hasil kegiatan penelitian dan pembahasan yang telah dijelaskan sebelumnya, maka dapat diambil kesimpulan sebagai berikut:

1. Strategi yang digunakan dalam pemasaran oleh pengusaha perempuan di Kabupaten Jember adalah dengan menciptakan sendiri barang dagangan dan menjual harga dibawah pasaran meskipun untungnya hanya sedikit, termasuk memberi imbuhan dan kelebihan barang dagangan pada pelanggan yang membeli dengan julah tertentu.

2. Pengembangan usaha yang dilakukan adalah dengan cara mencipatakan barang dagangan yang sebagus mungkin dan maksimal serta selalu berkonsisten membawa barang dagangan yang sama untuk menciptakan dan menanamkan rasa kepercayaan terhadap pelanggan bahwa baranng yanng akan dia cari selalu ada meskipun jumlahnya tidak sebanyak pada musim panen, termasuk tidak mengandalkan satu atau dua pemasok barang dagangan untuk menghindari minimnya pasokan barang dagang saat musim yang tidak menentu.

\section{Saran}

Atas hasil penelitian dan pembahasan di atas, maka diberikan saran-saran kepada beberapa pihak sebagai berikut :

1. Bagi para pelaku usaha perempuan pedagang sayuran

a. Strategi usaha yang dilakukan hendaknya diikuti dengan perkembangan teknologi informasi yangs semakin berkembang sekarang ini

b. Pembukuan keuangan hendaknya dilakukan dengan baik dan benar agar menjadi pedoman dalam berwirausaha secara berkelanjutan

2. Bagi pemerintah

a. Pemberian pengarahan mengenai strategi pemasarn perlu diadakan dipelosok desa terlebih kepada pengusaha perempuan

b. Akses permodalan hendaknya juga perlu dipermudah agar kegiatan usaha masyarakat dapat berjalan dengan lancar

c. Pelatihan kerja bagi perempuan terutama ibu rumah tangga perlu lebih digiatkan guna membangun masyarakat yang maksmur dan sejahtera

3. Bagi masyarakat 
a. Berfikir positif bahwa setiap kesuksesa dalam sebuah usah selalu ada hambatan dan tidak berjalan mulus, oleh seba itu perlu adanya ketekunan dan keyakinan.

b. Hendaknya mengikuti pelatihan kerja atuoun sejenisnya yang diadakan oelh pemerintah

c. Berkolaborasi dalam berbisnis bisa dijadikan solusi dalam melakukan sebuah usaha bagi para masyarakat luas jika dirasa kurang mampu dalam suatu bidang tertentu.

\section{DAFTAR PUSTAKA}

Amirudin, 2004. Pengantar Metode Penelitian Hukum, Jakarta: Raja Grafindo Persadam

Ardhanari, Margaretha, et. al. (2007). Analisis Personal Dan Struktural Pumik (Perempuan Pengusaha Mikro) Di Surabaya Dalam Upaya Pengembangan Keberhasilan Usaha Bidang Ritel. Makalah disampaikan pada Lokakarya Regional : "Pengembangan Kewirausahaan

Basu Swastha D.H. MBA, Manajemen pemasaran Modern, Liberty, Yogyakarta, 1990

Gitosudanno, Indriyo, Manajemen Pemasaran, BPFE Yogyakarta, 1994

Jati, Waluya. 2009. "Analisis Motivasi Wirausaha Perempuan (Wirausahatawati) di Kota Malang", Jurnal Humanity, Volume IV, Nomor 2, Maret 2009: 141 - 153

Jauch, lawrence R, Manajemen Strategis Dan Kebijakan Perusahaan, Erlangga, Jakarta, 1993

Lexy J. Moleong, Metodologi Penelitian Kualitatif, (Bandung: Remaja Rosdakarya, 2006), hlm. 6

M.B. Miles \&A.M. Huberman, Qualitative Data Analysis, (Beverly Hills, California: Sage Publication Inc., 1984), 21-23.

Margono. 2004. Metodologi Penelitian Pendidikan. Jakarta: Rineka Cipta

Maxwell, J.A.. 1996. Qualitattive Research Design: An Integrative Approach. London: Sage

Mc. Donald, Malcom H.B. Rencana Pemasaran, Arcan, Jakarta, 1995

Moleong, Lexy J. 1995. Metodologi Penelitian Kualitatif. Bandung: Remaja Rosdakarya

Phillip Kotler, Marketing Management, Prentice Hall, New Jersey, 2000

Naisbitt, John, Global Paradox, Avon Books, New York, 1995

S. Margono, 2005. Metodologi Penelitian Pendidikan, Jakarta: Rineka Cipta

S. Nasution, 1988. Metode PenelitianNaturalistik Kualitatif, Bandung: tarsito

Stanton, William, J, Prinsip Pemasaran, Erlangga, 1986

Sutojo Siswanto, Kerangka Dasar Manajemen Pemasaran, LPPM, 1981

Sofjian, Assauri, Manajemen Pemasaran Dasar, Konsep dan Strategi Rajawali, Jakarta,1992

Sugiyono. 2007. Memahami Penelitian Kualitatif. Bandung: CV Alfabeta

Sukardi. 2006. Penelitian Kualitatif-Naturalistik dalam Pendidikan. Jogjakarta: Penerbit Usaha Keluarga

Sutrisno, Hadi. 2007. Metodologi Research. Jogjakarta: Penerbit Andi

O. Winardi, Manajemen Pemasaran, Sinar Baru, Bandung, 1981

Zulminarni, Nani, 2004. "Lembaga Keuangan Mikro Dalam Rangka Pemberdayaan Perempuan Miskin", Disampaikan dalam acara workshop Berbagi Pengetahuan dan Sumberdaya Keuangan Mikro di Indonesia yang diselenggarakan oleh GEMA PKM Indonesia dan BWTP di Jakarta 27 Agustus 2004 